Original Article

\title{
First constitutive heterochromatin characterization and Karyotype of white stork Ciconia ciconia (Aves: Ciconiidae)
}

\author{
Primeira caracterização constitutiva de heterocromatina e cariótipo de cegonha- \\ branca Ciconia ciconia (Aves: Ciconiidae)
}

\author{
A. S. M. Abu Shnafa* (D) and M. S. Al-Khalifa ${ }^{\mathrm{b}}$ \\ ${ }^{a}$ Minia University, Faculty of Science, Department of Zoology and Entomology, Minia, Egypt

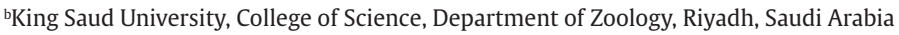

\begin{abstract}
The karyotype and constitutive heterochromatin pattern of the white stork Ciconia ciconia samples obtained from Manzala lake, Dimiaat, Egypt was described. Somatic cells of Ciconia ciconia samples have diploid number $2 \mathrm{n}=68$ chromosomes. Out of 68 chromosomes, 11 pairs including sex chromosomes were macrochromosomes and the remaining pairs were microchromosomes. Of the 11 macrochromosome pairs, no.1, 2, 4 and 5 were submetacentric and pairs no. 6, 7 and 8 were described as metacentric. In addition, the autosome pair no. 3 was subtelocentric, while autosome pair no.9 was acrocentric. Also, the sex chromosome $\mathrm{Z}$ represents the fourth one in size and it was classified as submetacentric while, W chromosome appeared as medium size and was acrocentric. Furthermore, C-banding pattern (constitutive heterochromatin) revealed variation in their sizes and occurrence between macrochromosomes. Pairs no. 7 and 8 of autosomes exhibited unusual distribution of heterochromatin, where they appeared as entirely heterochromatic. This may be related to the origin of sex chromosomes $\mathrm{Z}$ and $\mathrm{W}$. However, there is no sufficient evidence illustrate the appearance of entirely heterochromatic autosomes. Therefore, there is no available cytogenetic literature that describes the C-banding and karyotype of Ciconia Ciconia, so the results herein are important and may assist in cytogenetic study and evolutionary pattern of Ciconiiformes.
\end{abstract}

Keywords: karyotype, Ciconia ciconia, constitutive heterochromatin, Egypt.

\begin{abstract}
Resumo
O cariótipo e o padrão constitutivo de heterocromatina das amostras de cegonha-branca Ciconia ciconia obtidas no lago Manzala, Dimiaat, Egito, foram descritos. As células somáticas de amostras de Ciconia ciconia possuem número diploide $2 \mathrm{n}=68$ cromossomos. Dos 68 cromossomos, 11 pares incluindo cromossomos sexuais eram macrocromossomos e os pares restantes eram microcromossomos. Dos 11 pares de macrocromossomos, os $n^{\text {os }}$ 1, 2, 4 e 5 eram submetacêntricos, e os pares nos 6,7 e 8 foram descritos como metacêntricos. Além disso, 0 par de autossomos $n^{\circ} 3$ era subtelocêntrico, enquanto o par de autossomos $n^{\circ} 9$ era acrocêntrico. Além disso, o cromossomo sexual $\mathrm{Z}$ representa o quarto em tamanho e foi classificado como submetacêntrico, enquanto o cromossomo $\mathrm{W}$ apareceu como de tamanho médio e acrocêntrico. Além disso, o padrão de bandamento $\mathrm{C}$ (heterocromatina constitutiva) revelou variação em seus tamanhos e ocorrência entre macrocromossomos. Pares $\mathrm{n}^{\text {os }} 7$ e 8 dos autossomos exibiram distribuição incomum de heterocromatina, onde apareceram como totalmente heterocromáticos. Isso pode estar relacionado à origem dos cromossomos sexuais Z e W. No entanto, não há evidências suficientes para ilustrar o aparecimento de autossomos totalmente heterocromáticos. Portanto, não há literatura citogenética disponível que descreva o bandamento C e o cariótipo de Ciconia ciconia, portanto os resultados aqui apresentados são importantes e podem auxiliar no estudo citogenético e no padrão evolutivo de Ciconiiformes.
\end{abstract}

Palavras-chave: cariótipo, Ciconia ciconia, heterocromatina constitutiva, Egito.

\section{Introduction}

The white stork, Ciconia ciconia belongs to the Ciconiiformes, family Ciconiidae. It has white plumage with black feather on the wings, the adults have long red legs and pointed red beaks. The breeding season of these birds is in central and southern Europe, the Middle East and west-central Asia during the warm summer months. Ciconia ciconia migrates to southern Africa in winter. It prefers drier habitats including grasslands, cultivated

*e-mail: anwaarsalama78@yahoo.com

Received: February 16, 2021 - Accepted: April 27, 2021 
fields, and savannahs. In summer, they prefer freshwater habitats such as wet pastures, flood-plains, marshes, lakes and rice-fields for breeding.

Ciconiiformes are represented by five living families out of the seven which compose this major taxon (Sick and Barruel, 1997; Welty and Baptista, 1988). They include: Herons, Ibises, Spoonbills, and Storks. They are distinguished by long legs with slightly webbed feet and elongated toes. For feather maintenance, the middle toe of Ciconiiformes may be well developed. Most of them have long necks with vertebrae of 15 to 20 (Terry and Douglas, 2015). Wild populations of these birds are currently vulnerable in several important ecosystems, mainly due to some environmental modifications caused by human activities (Gariboldi et al., 1998). Families of Ciconiiformes are found in the Pantanal flood plain which extends throughout most of the Paraguay River hydrographic basin (Sick and Barruel, 1997) and Mycteria americana (Ciconiidae) and Platalea ajaja (Threskiornithidae) are more abundant species. However, the distribution of both species in Brazil has been reduced and several local populations are threatened with extinction or have already become extinct.

There are observable changes in the European population of the White Stork Ciconia ciconia, followed by a rapid decrease of reproduction success and an increase of mortality in the last five years (Daniluk et al., 2006; Kamiński et al., 2015; Peterson and Jakubiec, 2006). Therefore, it was found to concern Ciconia ciconia with cytogenetic study in this work. Although, there was some few karyotypic diversity reported for some Ciconiiformes, such as Threskiornithidae and Ciconiidae (Belterman and Boer, 1984, 1990; Boer and VanBrink, 1982; Boer, 1984; Mohanty and Bhunya, 1990 and Takagi and Sasaki, 1974). Moreover, the karyotype pattern of Threskiornithids is derived from that of Ciconiids (Takagi and Sasaki, 1974). The karyotypes of Brazilian species of Mycteria americana (Ciconiidae) and Platalea ajaja (Threskiornithidae) are described by Francisco and Galetti Junior (2000). The avian genome should be concerned with more knowledge because of the economic and biological importance of birds; their successful evolution. On the other side, only a few bird species have a sequenced genome such as chicken, turkey (Meleagris gallopave) and the zebra finch (Taeniopygia gutta). Sequenced genome of birds helps in knowing their origin, evolution and phylogeny (Dalloul et al., 2010; Hillier et al., 2004; Jarvis et al., 2014; Warren et al., 2010; Xu et al., 2014 and Zhang et al., 2014). Despite of the development of some DNA markers that help in detection of chicken microchromosomes, avian cytogenetics has not reached its full potential, and most bird cytogenetic data concerned only with macrochromosome (Damas et al., 2017; Lithgow et al., 2014; Romanov et al., 2014). On the other side, there was insufficient data about the chromosomal studies of Ciconiformes, especially white stork, Ciconia ciconia and chromosome relationships between Ciconiiform families which are still poorly understood. The objectives of this study were to: 1) Contribute to the pool of knowledge on the chromosome evolution of Ciconiiformes. 2) Describe the karyotype of white stork Ciconia ciconia. 3) Making genetic make-up for these migratory samples by heterochromatin characterization (C-banding).

\section{Materials and Methods}

\subsection{Sampling and study area}

White stork Ciconia ciconia samples were obtained by local fisherman from lake Manzala, Damietta, during April to July month, 2015 year. Manzala is the largest natural lake of the Egyptian northern lakes along the Mediterranean coast in Egypt and is located between longitudes $31^{\circ} 45^{\prime}$ and $32^{\circ} 22^{\prime} \mathrm{E}$ and latitudes $31^{\circ} 00^{\prime}$ and $31^{\circ} 35^{\prime} \mathrm{N}$. It is one of the most vulnerable lakes. It is an example of the wetland in Egypt and it was famous with water birds and a migration route for some birds from Europe to Africa along the Mediterranean Sea (Ayache et al., 2009).

\subsection{Conventional preparation}

The mitotic chromosome preparations were carried out according to air drying method (Yosida, 1973) with some modifications by Ata et al. (2005, 2019). About 50 metaphase plates from each sample were examined at X100 magnification and good spreads were photographed using an Olympus BX51 microscope with a C-4040 zoom digital camera. The karyotype was determined on the basis of 10 well-spread metaphase cells from each sample. Macrochromosomes were measured under the microscope using the Soft Imaging System (SIS) analysis program (Version3.0) edited in 1999 by Soft Imaging System $\mathrm{GmbH}$, Germany, and classified according to the system of nomenclature proposed by Levan et al. (1964).

\subsection{C-banding technique}

C-bands were obtained according to the standard protocol of Sumner (1972) with major modifications as described by Ata et al. $(2005,2019)$ and Shahin et al. (2014). At least 10 metaphase spreads of each bird were photographed and analyzed using Olympus BX51 microscope with a C-4040 zoom digital camera. The $\mathrm{C}$-band sizes and distribution on the macrochromosomes of Ciconia ciconia samples were described and the number of heterochromatin blocks per micro-chromosomes in the examined cells was recorded. The ideogram was constructed using Microsoft Excel 2010 program according to karyological measurements on white stork Ciconia ciconia samples.

\section{Results}

\subsection{Karyotype}

Results of the examined mitotic spreads of Ciconia ciconia samples obtained from Manzala lake, Damietta revealed that the diploid number of chromosomes was $2 n=68$. The chromosome set consists of 11 pairs, including sex chromosomes are macrochromosomes, while the remaining pairs are microchromosomes. Of the 10 autosomes macrochromosome pairs, pairs no.1, 2, 4 and 5 were submetacentric with total length ranging from $2.31 \pm 0.16 \mu \mathrm{m}$ to $6.78 \pm 0.46 \mu \mathrm{m}$; pairs no. $6,7,8$ and 10 were classified as metacentric with total length ranged from $1.11 \pm 0.14 \mu \mathrm{m}$ to $1.86 \pm 0.18 \mu \mathrm{m}$ as in Table 1 and Figure 1 . In addition, the autosome pair no. 3 was subtelocentric with 
Table 1. Measurements and nomenclature of macrochromosomes of white stork Ciconia Ciconia.

\begin{tabular}{|c|c|c|c|c|c|}
\hline Chromosome pair No. & Short arm (p) & Long arm (q) & Total length $(T)$ & Arm ratio $\mathbf{q} / \mathbf{p}$ & $\begin{array}{c}\text { Nomenclature } \\
\text { (Levan et al., 1964) }\end{array}$ \\
\hline 1 & $2.54 \pm 0.64$ & $4.24 \pm 0.18$ & $6.78 \pm 0.46$ & $1.78 \pm 0.59$ & $\mathrm{Sm}$ \\
\hline 2 & $1.66 \pm 0.34$ & $3.48 \pm 0.21$ & $5.14 \pm 0.48$ & $2.14 \pm 0.40$ & $\mathrm{Sm}$ \\
\hline 3 & $0.96 \pm 0.19$ & $2.91 \pm 0.62$ & $3.87 \pm 0.48$ & $3.19 \pm 1.31$ & St \\
\hline 4 & $0.95 \pm 0.12$ & $1.85 \pm 0.49$ & $2.79 \pm 0.45$ & $1.89 \pm 0.89$ & $\mathrm{Sm}$ \\
\hline 5 & $0.83 \pm 0.27$ & $1.48 \pm 0.128$ & $2.31 \pm 0.16$ & $1.99 \pm 0.93$ & $\mathrm{Sm}$ \\
\hline 6 & $0.77 \pm 0.13$ & $1.09 \pm 0.07$ & $1.86 \pm 0.18$ & $1.43 \pm 0.21$ & M \\
\hline 7 & $0.74 \pm 0.01$ & $0.91 \pm 0.06$ & $1.66 \pm 0.04$ & $1.20 \pm 0.10$ & M \\
\hline 8 & $0.67 \pm 0.03$ & $0.79 \pm 0.06$ & $1.47 \pm 0.046$ & $1.17 \pm 0.13$ & M \\
\hline 9 & - & $1.21 \pm 0.16$ & $1.21 \pm 0.16$ & - & $\mathrm{T}$ \\
\hline 10 & $0.46 \pm 0.13$ & $0.64 \pm 0.011$ & $1.11 \pm 0.14$ & $1.46 \pm 0.39$ & M \\
\hline Z & $1.09 \pm 0.16$ & $2.01 \pm 0.71$ & $3.10 \pm 0.65$ & $1.89 \pm 0.89$ & $\mathrm{Sm}$ \\
\hline W & - & $1.10 \pm 0.12$ & $1.10 \pm 0.12$ & - & $\mathrm{T}$ \\
\hline
\end{tabular}
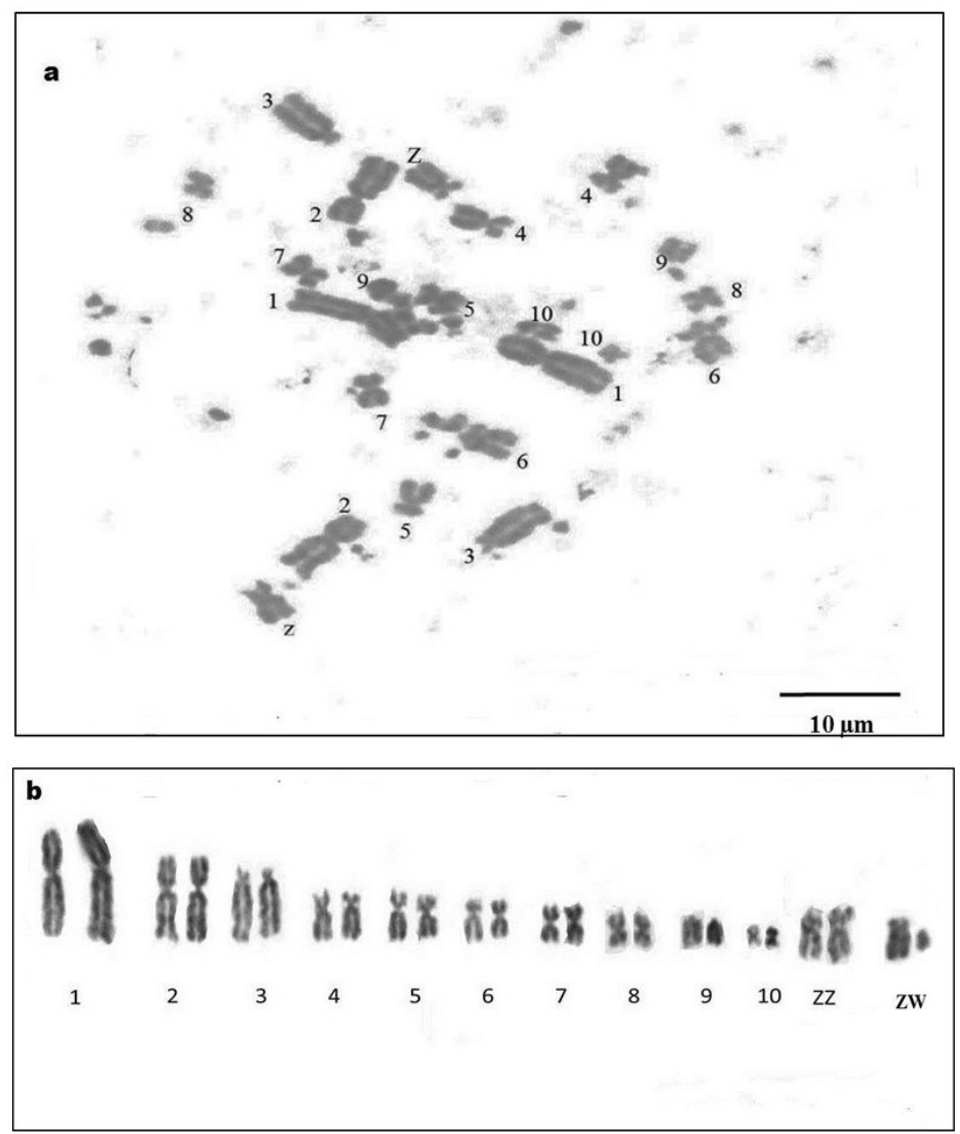

Figure 1. Image of metaphase cell chromosomes (a) and karyotype (b) of male white stork Ciconia ciconia collected from Manzala lake, Dimette. Note the female ZW chromosomes are added in (b), numbers refer to macrochromosomes.

total length $3.87 \pm 0.48 \mu \mathrm{m}$, while autosome pair no.9 was acrocentric and its size was $1.21 \pm 0.16 \mu \mathrm{m}$. Moreover, the sex chromosome $Z$ represents the fourth one in size and it was classified as submetacentric while, $\mathrm{W}$ chromosome appeared as medium size and was acrocentric.

\subsection{Constitutive heterochromatin description (C-banding)}

The results of $\mathrm{C}$-banding revealed variation in their sizes and occurrence between macrochromosomes as in Figure 2. In the present study, chromosome pair no.1 and 2 have small to medium sized telomeric C-band while 

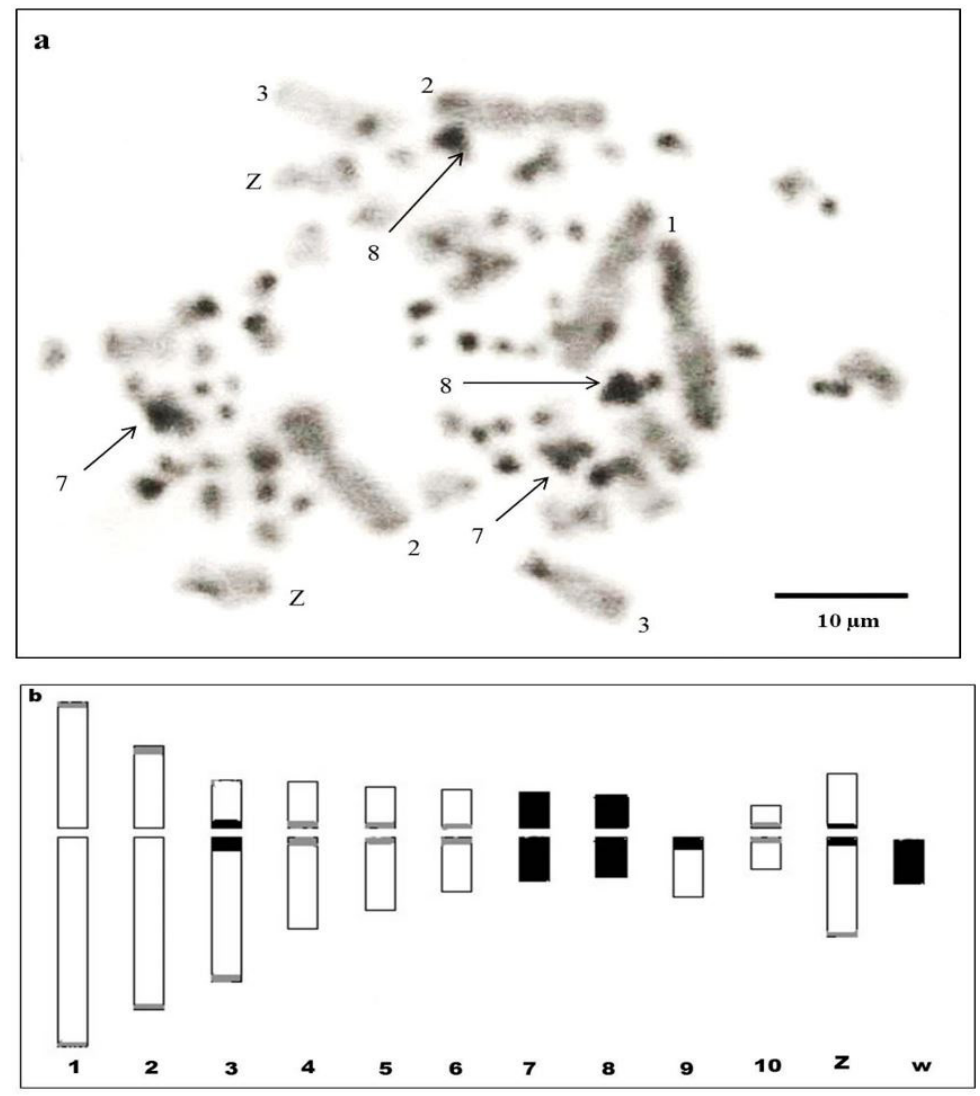

Figure 2. Image of C-band metaphase spread (a) of the male white stork Ciconia ciconia, and an Ideogram (b) of macro-chromosomes illustrates the position and size of C-heterochromatin in it. Note arrows indicate to pairs no.7 and 8 (entirely heterochromatic) and W chromosome is added to the Ideogram (b).

chromosome pair no.3 has large centromeric C-band in addition to faint telomeric distal C-band. However, the acrocentric chromosome pair no.9 has large block of C-band. Moreover, the remained biarmed autosomes have varied size centromeric C-band except autosome pairs no. 7 and 8 appeared completely entirely heterochromatic. In the other hand, the sex chromosome $Z$ has medium sized centromeric C-band in addition to telomeric (distal) part. In addition to the description of C-banding on macrochromosomes, constitutive heterochromatin dots were counted in each metaphase set in all the examined samples of Ciconia ciconia. The results revealed that the mean number of $\mathrm{C}$-band blocks on microchromosomes per cell was $(25.33 \pm 2.1)$.

\section{Discussion}

There was no previous data on the karyotype and C-banding pattern of white stork Ciconia Ciconia, so the data presented herein are important. Therefore, it helps in animal reproduction program and takes part in the pool of knowledge on chromosome evolution of Ciconiiformes. In the present study, chromosomal results of white stork Ciconia Ciconia collected from Manzala lake, Damietta revealed that the diploid number of chromosomes was
$2 \mathrm{n}=68$. According to the parallel studies on Ciconiidae, Francisco and Galetti Junior (2000) reported that Mycteria americana had a diploid number $2 \mathrm{n}=72$, which was karyotypically similar to the previously described Mycteria cinerea (Belterman and Boer, 1990). In addition, (Belterman and Boer, 1990) Mycteria cinerea (2n=72) may represent the ancestral karyotype of Ciconiids. The results in the present study were in consistent with the previously reported by Belterman and Boer (1984); Belterman and Boer (1990); Boer and Van Brink (1982) and Takagi and Sasaki (1974) in which there was decreasing in the number of microchromosomes among these species. The reduction in some genome of birds may be an adaptive characteristic due to natural selection. Moreover, some authors observed that the excellent flayer birds have small genome than the largest one which is present in unflying birds (Hughes and Hughes, 1995; Hughes, 1999). However, this opinion was doubted, because there was no sufficient evidence showing which came first, the ability to fly, or the decrease in genome size (Gregory, 2002; Waltari and Edwards, 2002). The decreasing in number of microchromosomes may be a common chromosome evolutionary strategy in some bird groups (Francisco and Galetti Junior, 2000). Besides, the reduction in number of micochromosomes 
may be due to chromosomal fusion (Nanda et. al., 2007). Moreover, the appearance of biarmed chromosomes may be due to occurrence of reciprocal translocation.

In the present study, results of karyotype revealed that of 68 chromosomes, 11 pairs, including sex chromosomes are macrochromosomes, while the remaining pairs are microchromosomes. Of the 10 autosomes macrochromosome, pairs no.1, 2, 4 and 5 were submetacentric that was in disagreement with Francisco and Galetti Junior (2000) in Mycteria americana (Ciconidae). On contrary, results here in was in agreement with Francisco and Galetti Junior (2000) in Mycteria americana (Ciconidae) in which chromosome pair no.3 was subteloceentric; pair no.9; W chromosome was telocentric and $Z$ chromosome was submetacentric. The maintenance of a similar karyotype in Mycteria americana suggests a conservative chromosome evolutionary pattern within this genus. On the other side, the autosomes pairs no. $6,7,8$ and 10 were metacentric.

Regarding the description of constitutive heterochromatin (C-banding) of the white stork Ciconia ciconia, there is no previously available literatures which describe the C-banding of Ciconia ciconia. In the present study, Pattern of constitutive heterochromatin of the white stork Ciconia ciconia represented by occurrence of variable sized centromeric C- bands in all macrochromosomes except autosome pairs nos. 1 and 2 that have faint heterochromatin on the telomeric region. Chromosome pair no.3 has large centromeric C-band in addition to faint telomeric distal C-band. However, the acrocentric chromosome pair no.9 has large block of C-band while the remained biarmed pairs no. 4, 5, 6 and 10 autosomes have varied sizes of centromeric C-band. Moreover, the submetacentric $\mathrm{Z}$ chromosome has a small sized centromeric C-band in addition to faint distal portion. From the above-mentioned results, the obvious variation of C-banding distribution in white stork chromosomes may be attributed to the variation of euchromatin with chromosome size and arrangement of constitutive heterochromatin as reported by previous studies on avian taxa (Ata et al., 2005, 2017, 2019; Shahin et al., 2014; Yosida, 1973). On the other hand, chromosome pairs no. 7 and 8 appeared entirely heterochromatic as well as W sex chromosome. This unusual distribution of constitutive hetrochromatin on somatic chromosomes was previously reported by some studies on aves as in ducks (Ata et al., 2019), passerine bird Erithacus savecicus (Bhunya and Sultana, 1982). However, there is no sufficient evidence illustrate this phenomenon. On the other hand, Bergero and Charlesworth, 2009; Mank, 2013 reported that appearance of entirely heterochromatic autosome may be related to the origin of $\mathrm{Z}$ and $\mathrm{W}$ sex chromosomes which, they thought that sex chromosomes might arise from the somatic chromosomes throughout recombination and/or chromosomal exchanges during evolutionary processes. Additionally, the C-banding heterochromatin dots of microchromosomes in the present study were small. This could be attributed to either transformation of heterochromatin into euchromatin and vice versa (Ata et al., 2019; King, 1991; Shahin et al., 2014) or to involvement of structural chromosomal aberrations during karyotype evolution (White, 1973).

\section{Conclusion}

The diploid chromosome number of white storks Ciconia Ciconia collected from Manzala lake, Damietta was $2 n=68$ chromosomes. 11 pairs, including sex chromosomes are macrochromosomes, while the remaining pairs are microchromosomes. C-banding description of the white stork Ciconia ciconia showed variable sized centromeric C- bands in all macrochromosomes except autosome pairs nos. 1 and 2 that have faint heterochromatin on the telomeric region. In addition, autosomes pairs no. 7 and 8 appeared entirely heterochromatic.

\section{Acknowledgements}

This work was supported by Researchers Supporting Project number (RSP-2021-104) King Saud University, Riyadh, Saudi Arabia. Grateful acknowledgment is to Prof. Dr. Abdeltawab M. Ata, department of Genetics, faculty of Agriculture, Minia University, for his truthful help in reviewing the paper.

\section{References}

ATA, A. M., ABUUSALHA, A. E., ALLAM, H. Z. and FANDY, W. M., 2017. Karyological studies on some breeds of duck. Minia Journal of Agricultural Research and Development, vol. 37, no. 1, pp. 61-81.

ATA, A. M., ALLAM, H. Z., ABUUSALHA, A. E., FANDY, W. M. and SHNAF, A.S.M.A., 2019. Constitutive heterochromatin pattern of five domestic duck breeds, (Aves: Anatidae) in Egypt. Egyptian Academic Journal of Biological Sciences, vol. 11, no. 2, pp. 57-69.

ATA, A.M., SALHA, A.E.A., ALLAM, H.Z. and FANDY, W.A., 2005. Cytogenetic studies on three species of domestic birds (Galliformes, Aves): I-chromosomal morphology and C-banding analysis. Minia Journal of Agricultural Research and Development, vol. 25, pp. 977-1000.

AYACHE, F., THOMPSON, J., FLOWER, J., BOUJARRA, A., ROUATBI, F. and MAKINA, H., 2009. Environmental characteristics, landscape history and pressures on three coastal lagoons in the Southern Mediterranean Region: Merja Zerga (Morocco), Ghar El Melh (Tunisia) and Lake Manzala (Egypt). Hydrobiologia, vol. 622, pp. 15-43. http://dx.doi.org/10.1007/s10750-008-9676-6.

BELTERMAN, R.H.B. and BOER, L.E.M., 1984. A karyological study of 55 species of birds, including karyotypes of 39 species new to cytology. Genetica, vol. 65, no. 1, pp. 39-82. http://dx.doi. org/10.1007/BF00056765.

BELTERMAN, R.H.B. and BOER, L.E.M., 1990. A miscellaneous collection of bird karyotypes. Genetica, vol. 83, no. 1, pp. 17-29. http://dx.doi.org/10.1007/+BF00774685.

BERGERO, R. and CHARLESWORTH, D., 2009. The evolution of restricted recombination in sex chromosomes. Trends in Ecology E' Evolution, vol. 24, no. 2, pp. 94-102. http://dx.doi. org/10.1016/j.tree.2008.09.010. PMid:19100654.

BHUNYA, S.P. and SULTANA, T., 1982. Unusual distribution of constitutive heterochromatin C-bands in the somatic chromosomes of a passerine bird Erithacus Svecicus. Experientia, vol. 38, no. 7, pp. 806-807. http://dx.doi.org/10.1007/BF01972283.

BOER, L.E.M. and VAN BRINK, J.M., 1982. Cytotaxonomy of Ciconiiformes (Aves), with karyotypes of eight species new to cytology. Cytogenetics and Cell Genetics, vol. 34, no. 1-2, pp. 19-34. http://dx.doi.org/10.1159/000131791. PMid:7151490. 
BOER, L.E.M., 1984. New developments in vertebrate cytotaxonomy VIII. A current list of references on avian karyology. Genetica, vol. 65, no. 1, pp. 3-6. http://dx.doi.org/10.1007/BF00056763.

DALLOUL, R.A., LONG, J.A., ZIMIN, A.V., ASLAM, L., BEAL, K., BLOMBERG, L.A., BOUFFARD, P., BURT, D.W., CRASTA, O., CROOIJMANS, R.P., COOPER, K., COULOMBE, R.A., DE, S., DELANY, M.E., DODGSON, J.B., DONG, J.J., EVANS, C., FREDERICKSON, K.M., FLICEK, P., FLOREA, L., FOLKERTS, O., GROENEN, M.A., HARKINS, T.T., HERRERO, J., HOFFMANN, S., MEGENS, H.J., JIANG, A., DE JONG, P., KAISER, P., KIM, H., KIM, K.W., KIM, S., LANGENBERGER, D., LEE, M.K., LEE, T., MANE, S., MARCAIS, G., MARZ, M., MCELROY, A.P., MODISE, T., NEFEDOV, M., NOTREDAME, C., PATON, I.R., PAYNE, W.S., PERTEA, G., PRICKETT, D., PUIU, D., QIOA, D., RAINERI, E., RUFFIER, M., SALZBERG, S.L., SCHATZ, M.C., SCHEURING, C., SCHMIDT, C.J., SCHROEDER, S., SEARLE, S.M., SMITH, E.J., SMITH, J., SONSTEGARD, T.S., STADLER, P.F., TAFER, H., TU, Z.J., VAN TASSELL, C.P., VILELLA, A.J., WILLIAMS, K.P., YORKE, J.A., ZHANG, L., ZHANG, H.B., ZHANG, X., ZHANG, Y. and REED, K.M., 2010. Multi-platform Next Generation sequencing of the domestic turkey (Meleagris gallopavo). PLoS Biology, vol. 8, no. 9, pp. e1000475. http://dx.doi.org/10.1371/ journal.pbio.1000475. PMid:20838655.

DAMAS, J., O'CONNOR, R., FARRÉ, M., LENIS, V.P.E., MARTELL, H.J., MANDAWALA, A., FOWLER, K.E., JOSEPH, S., SWAIN, M., GRIFFIN, D.K. and LARKIN, D.M., 2017. Upgrading short-read animal genome assemblies to chromosome level using comparative genomics and a universal probe set. Genome Research, vol. 27, no. 5, pp. 875-884. http://dx.doi.org/10.1101/gr.213660.116. PMid:27903645.

DANILUK, J., DANILUK-KORBAL, A. and MITRUS, C., 2006. Changes in population size, breeding success and nest location of a local White Stork Ciconia ciconia population in Eastern Poland. In: P. TRYJANOWSKI, T.H. SPARKS and L. JERZAK, eds. The White Stork in Poland: studies in biology, ecology and conservation. Poznań: BoguckiWyd. Nauk, pp 15-21.

FRANCISCO, M.R. and GALETTI JUNIOR, P.M., 2000. First karyotypical description of two American Ciconiiform birds, Mycteria Americana (Ciconiidae) and Platalea ajaja (Threskiornithidae) and its significance for the chromosome evolutionary and biological conservation approaches. Genetics and Molecular Biology, vol. 23, no. 4, pp. 799-801. http://dx.doi.org/10.1590/ S1415-47572000000400015.

GARIBOLDI, J.C., JAGOE, C.H. and BRYAN JUNIOR, A.L., 1998. Dietary exposure to mercury in nestling wood storks (Mycteria americana) in Georgia. Archives of Environmental Contamination and Toxicology, vol. 34, no. 4, pp. 398-405. http://dx.doi. org/10.1007/s002449900336. PMid:9543511.

GREGORY, T. R. 2002. Genome size and developmental complexity. Genetica, vol. 115, pp. 131-146.

SHAHIN, A.A., ATA, A.T. and SHNAF, A.S., 2014. Karyotype and C-banding pattern of the domestic geese Anser anser populations (Aves: Anatidae) in Egypt. Folia Biologica, vol. 62, no. 1, pp. 49-58. PMid:24745149.

HILLIER, L.D., MILLER, W., BIRNEY, E., WARREN, W., HARDISON, R., PONTING, C.P., BORK, P., BURT, D.W., GROENEN, M.A.M., DELANY, M.E., 2004. Sequence and comparative analysis of the chicken genome provide unique perspectives on vertebrate evolution. Nature, vol. 432, no. 7018, pp. 695-716. http://dx.doi. org/10.1038/nature03154. PMid:15592404.

HUGHES, A.L. and HUGHES, M.K., 1995. Small genomes for better flyers. Nature, vol. 377, no. 6548, pp. 391. http://dx.doi. org/10.1038/377391a0. PMid:7566113.

HUGHES, A.L., 1999. Adaptive evolution of genes and genomes. Oxford: Oxford University Press.
JARVIS, E.D., MIRARAB, S., ABERER, A.J., LI, B., HOUDE, P., LI, C., HO, S.Y., FAIRCLOTH, B.C., NABHOLZ, B., HOWARD, J.T., SUH, A., WEBER, C.C., DA FONSECA, R.R., LI, J., ZHANG, F., LI, H., ZHOU, L., NARULA, N., LIU, L., GANAPATHY, G., BOUSSAU, B., BAYZID, M.S., ZAVIDOVYCH, V., SUBRAMANIAN, S., GABALDÓN, T., CAPELLAGUTIÉRREZ, S., HUERTA-CEPAS, J., REKEPALLI, B., MUNCH, K., SCHIERUP, M., LINDOW, B., WARREN, W.C., RAY, D., GREEN, R.E., BRUFORD, M.W., ZHAN, X., DIXON, A., LI, S., LI, N., HUANG, Y., DERRYBERRY, E.P., BERTELSEN, M.F., SHELDON, F.H., BRUMFIELD, R.T., MELLO, C.V., LOVELL, P.V., WIRTHLIN, M., SCHNEIDER, M.P., PROSDOCIMI, F., SAMANIEGO, J.A., VELAZQUEZ, A.M.V., ALFARONÚÑEZ, A., CAMPOS, P.F., PETERSEN, B., SICHERITZ-PONTEN, T., PAS, A., BAILEY, T., SCOFIELD, P., BUNCE, M., LAMBERT, D.M., ZHOU, Q., PERELMAN, P., DRISKELL, A.C., SHAPIRO, B., XIONG, Z., ZENG, Y., LIU, S., LI, Z., LIU, B., WU, K., XIAO, J., YINQI, X., ZHENG, Q., ZHANG, Y., YANG, H., WANG, J., SMEDS, L., RHEINDT, F.E., BRAUN, M., FJELDSA, J., ORLANDO, L., BARKER, F.K., JØNSSON, K.A., JOHNSON, W., KOEPFLI, K.P., O'BRIEN, S., HAUSSLER, D., RYDER, O.A., RAHBEK, C., WILLERSLEV, E., GRAVES, G.R., GLENN, T.C., MCCORMACK, J., BURT, D., ELLEGREN, H., ALSTRÖM, P., EDWARDS, S.V., STAMATAKIS, A., MINDELL, D.P., CRACRAFT, J., BRAUN, E.L., WARNOW, T., JUN, W., GILBERT, M.T. and ZHANG, G., 2014. Whole-genome analyses resolve early branches in the tree of life of modern birds. Science, vol. 346, no. 6215, pp. 13201331. http://dx.doi.org/10.1126/science.1253451. PMid:25504713.

KAMIŃSKI, P., GROCHOWSKA, E., MROCZKOWSKI, S., JERZAK, L., KASPRZAK, M., KOIM-PUCHOWSKA, B., WOŹNIAK, A., CIEBIERA, O. and MARKULAK, D., 2015. Sex ratio of White Stork Ciconia ciconia in different environments of Poland. Environmental Science and Pollution Research International, vol. 22, no. 17, pp. 13194-13203. http://dx.doi.org/10.1007/s11356-015-4250-z. PMid:25940461.

KING, M., 1991. The evolution of heterochromatin in amphibian genome. In: D. M. GREEN and S. K. SESSIONS, eds. Amphipian Cytogenetics and Evolution. New York: Academic Press, pp. 359-381.

LEVAN, A., FREDGA, K. and SANDBERG, A., 1964. Nomenclature for centromeric position on chromosomes. Hereditas, vol. 52, no. 2, pp. 201-220. http://dx.doi.org/10.1111/j.1601-5223.1964.tb01953.x.

LITHGOW, P.E., O'CONNOR, R., SMITH, D., FONSEKA, G., AL MUTERY, A., RATHJE, C., FRODSHAM, R., O'BRIEN, P., KASAI, F., FERGUSONSMITH, M.A., SKINNER, B.M. and GRIFFIN, D.K., 2014. Novel tools for characterizing inter and intra chromosomal rearrangements in avian microchromosomes. Chromosome Research, vol. 22, no. 1, pp. 85-97. PMid:24696127.

MANK, J.E., 2013. Sex chromosome dosage compensation: definitely not for everyone. Trends in Genetics, vol. 29, no. 12, pp. 677-683. http://dx.doi.org/10.1016/j.tig.2013.07.005. PMid:23953923.

MOHANTY, M.K. and BHUNYA, S.P., 1990. Karyological studies in four species of ardeidae birds (Ardeidae, Ciconiiformes). Genetica, vol. 81, no. 3, pp. 211-214. http://dx.doi.org/10.1007/BF00360867.

NANDA, I., KARL, E., GRIFFIN, D.K., SCHARTL, M. and SCHMID, M., 2007. Chromosome re-patterning in three representative parrots (Psittaciformes) inferred from comparative chromosome painting. Cytogenetic and Genome Research, vol. 117, no. 1-4, pp. 43-53. http://dx.doi.org/10.1159/000103164. PMid:17675844.

PETERSON, U. and JAKUBIEC, Z., 2006. Long-term studies of population dynamics and reproduction of the White Stork Ciconia ciconia in the region of its highest density. In: P. TRYJANOWSKI, T.H. SPARKS and L. JERZAK, eds. The White Stork in Poland: studies in biology, ecology and conservation. Poznań: BoguckiWyd. Nauk, pp 35-46.

ROMANOV, M. N., FARRÉ, M., LITHGOW, P. E., FOWLER, K. E., SKINNER, B. M., O'CONNOR, R., FONSEKA, G., BACKSTRÖM, N., MATSUDA, Y., NISHIDA, C., HOUDE, P., JARVIS, E.D., ELLEGREN, H., BURT, 
D.W., LARKIN, D.M. and GRIFFIN, D.K., 2014. Reconstruction of gross avian genome structure, organization and evolution suggests that the chicken lineage most closely resembles the dinosaur avian ancestor. BMC Genome, vol. 15, p. 1060.

SICK, H. and BARRUEL, P., 1997. Ornitologia Brasileira, uma Introdução. Sao Paulo: Nova Fronteira. 912 p.

SUMNER, A.T., 1972. A simple technique for demonstrating centromeric heterochromatin. Experimental Cell Research, vol. 75, no. 1, pp. 304-306. http://dx.doi.org/10.1016/0014-4827(72)90558-7. PMid:4117921.

TAKAGI, N. and SASAKI, M., 1974. A phylogenetic study of bird karyotypes. Chromosoma, vol. 46, no. 1, pp. 91-120. http:// dx.doi.org/10.1007/BF00332341. PMid:4134896.

TERRY, M. and DOUGLAS, P., 2015. Whiteside. In: R.E. MILLER and M.E. FOWLER, eds. Fowler's Zoo and Wild Animal Medicine. St. Louis: Elsevier.

WALTARI, E. and EDWARDS, S.V., 2002. Evolutionary dynamics of intron size, genome size, and physiological correlates in archosaurs. The American Naturalist, vol. 160, no. 5, pp. 539-552. https://doi.org/10.1086/342079.

WARREN, W.C., CLAYTON, D.F., ELLEGREN, H., ARNOLD, A.P., HILLIER, L.W., KÜNSTNER, A., SEARLE, S., WHITE, S., VILELLA, A.J., FAIRLEY, S., HEGER, A., KONG, L., PONTING, C.P., JARVIS, E.D., MELLO, C.V., MINX, P., LOVELL, P., VELHO, T.A., FERRIS, M., BALAKRISHNAN, C.N., SINHA, S., BLATTI, C., LONDON, S.E., LI, Y., LIN, Y.C., GEORGE, J., SWEEDLER, J., SOUTHEY, B., GUNARATNE, P., WATSON, M., NAM, K., BACKSTRÖM, N., SMEDS, L., NABHOLZ, B., ITOH, Y., WHITNEY, O., PFENNING, A.R., HOWARD, J., VÖLKER, M., SKINNER, B.M., GRIFFIN, D.K., YE, L., MCLAREN, W.M., FLICEK, P., QUESADA, V., VELASCO, G., LOPEZ-OTIN, C., PUENTE, X.S., OLENDER, T., LANCET, D., SMIT, A.F., HUBLEY, R., KONKEL, M.K., WALKER, J.A., BATZER, M.A., GU, W., POLLOCK, D.D., CHEN, L., CHENG, Z., EICHLER, E.E., STAPLEY, J., SLATE, J., EKBLOM, R., BIRKHEAD, T., BURKE, T., BURT, D., SCHARFF, C., ADAM, I., RICHARD, H., SULTAN, M., SOLDATOV, A., LEHRACH, H., EDWARDS, S.V., YANG, S.P., LI, X., GRAVES, T., FULTON, L., NELSON, J., CHINWALLA, A., HOU, S., MARDIS, E.R. and WILSON, R.K., 2010. The genome of a song bird. Nature, vol. 464, no. 7289, pp. 757-762. http://dx.doi.org/10.1038/ nature08819. PMid:20360741.

WELTY, J.C. and BAPTISTA, L., 1988. The Life of Birds. 4th ed. Orlando: Saunders College Publishing.
WHITE, M. J. D., 1973. Animal Cytology and Evolution. 3rd ed. Cambridge: Cambridge University Press.

XU, X., ZHOU, Z., DUDLEY, R., MACKEM, S., CHUONG, C., ERICKSON, G.M. and VARRICCHIO, D.J., 2014. An integrative approach to understanding bird origins. Science, vol. 346, no. 6215, pp. 1253293. http://dx.doi.org/10.1126/science.1253293.

YOSIDA, T.H., 1973. Evolution of karyotype and differentiation in 13 Rattus species. Chromosoma, vol. 40, pp. 285-297.

ZHANG, G., LI, C., LI, Q., LI, B., LARKIN, D.M., LEE, C., STORZ, J.F., ANTUNES, A., GREENWOLD, M.J., MEREDITH, R.W., ÖDEEN, A., CUI, J., ZHOU, Q., XU, L., PAN, H., WANG, Z., JIN, L., ZHANG, P., HU, H., YANG, W., HU, J., XIAO, J., YANG, Z., LIU, Y., XIE, Q., YU, H., LIAN, J., WEN, P., ZHANG, F., LI, H., ZENG, Y., XIONG, Z., LIU, S., ZHOU, L., HUANG, Z., AN, N., WANG, J., ZHENG, Q., XIONG, Y., WANG, G., WANG, B., WANG, J., FAN, Y., DA FONSECA, R.R., ALFARO-NÚÑEZ, A., SCHUBERT, M., ORLANDO, L., MOURIER, T., HOWARD, J.T., GANAPATHY, G., PFENNING, A., WHITNEY, O., RIVAS, M.V., HARA, E., SMITH, J., FARRÉ, M., NARAYAN, J., SLAVOV, G., ROMANOV, M.N., BORGES, R., MACHADO, J.P., KHAN, I., SPRINGER, M.S., GATESY, J., HOFFMANN, F.G., OPAZO, J.C., HÅSTAD, O., SAWYER, R.H., KIM, H., KIM, K.W., KIM, H.J., CHO, S., LI, N., HUANG, Y., BRUFORD, M.W., ZHAN, X., DIXON, A., BERTELSEN, M.F., DERRYBERRY, E., WARREN, W., WILSON, R.K., LI, S., RAY, D.A., GREEN, R.E., O'BRIEN, S.J., GRIFFIN, D., JOHNSON, W.E., HAUSSLER, D., RYDER, O.A., WILLERSLEV, E., GRAVES, G.R., ALSTRÖM, P., FJELDSÅ, J., MINDELL, D.P., EDWARDS, S.V., BRAUN, E.L., RAHBEK, C., BURT, D.W., HOUDE, P., ZHANG, Y., YANG, H., WANG, J., JARVIS, E.D., GILBERT, M.T., WANG, J., YE, C., LIANG, S., YAN, Z., ZEPEDA, M.L., CAMPOS, P.F., VELAZQUEZ, A.M.V., SAMANIEGO, J.A., AVILA-ARCOS, M., MARTIN, M.D., BARNETT, R., RIBEIRO, A.M., MELLO, C.V., LOVELL, P.V., ALMEIDA, D., MALDONADO, E., PEREIRA, J., SUNAGAR, K., PHILIP, S., DOMINGUEZ-BELLO, M.G., BUNCE, M., LAMBERT, D., BRUMFIELD, R.T., SHELDON, F.H., HOLMES, E.C., GARDNER, P.P., STEEVES, T.E., STADLER, P.F., BURGE, S.W., LYONS, E., SMITH, J., MCCARTHY, F., PITEL, F., RHOADS, D. and FROMAN, D.P., 2014. Comparative genomics reveals insights into avian genome evolution and adaptation. Science, vol. 346, no. 6215, pp. 1311-1320. http://dx.doi.org/10.1126/science.1251385. PMid:25504712. 